WSHC-RP-92-1158

\title{
Hg REMOVAL FROM SRTC LABORATORY WASTE USING AN IN-TANK ION EXCHANGE PROBE (U)
}

by J.P. Bibler

WSRC-RP--92-1158

Westinghouse Savannah River Company

DE93 006168

Savannah River Site

Aiken, South Carolina 29808

Other Authors:

J. J. DeGange

This paper was prepared in connection with work done under Contract No. DE-AC09-89SR18035 with the U. S. Department of Energy. By acceptance of this paper, the publisher and/or recipient acknowledges the U.S. Government's right to retain a nonexclusive, royalty-free license in and to any copyright covering this paper, along with the right to reproduce and to authorize others to reproduce all or part of the copyrighted paper. 


\section{DISCLAIMER}

This report was prepared as an account of work sponsored by an agency of the United States Government. Neither the United States Government nor any agency thereof, nor any of their employees, makes any warranty, express or implied, or assumes any legal liability or responsibility for the accuracy, completeness, or usefulness of any information, apparatus, product, or process disclosed, or represents that its use would not infringe privately owned rights. Reference herein to any specific commercial product, process, or service by trade name, trademark, manufacturer, or otherwise does not necessarily constitute or imply its endorsement, recommendation, or favoring by the United States Government or any agency thereof. The views and opinions of authors expressed herein do not necessarily state or reflect those of the United States Governisent or any agency thereof.

This report has been reproduced directly from the best available copy.

Available to DOE and DOE contractors from the Office of Scientific and Technical Information, P.O. Box 62, Oak Ridge, TN 37831; prices available from (615) 576-8401, FTS 626-8401.

Available to the public from the National Technical Information Service, U.S. Department of Commerce, 5285 Port Royal Rd., Springfield, VA 22161. 
WESTINGHOUSE SAVANNAH RIVER COMPANY SAVANNAH RIVER TECHNOLOGY CENTER
WSRC-RP-92-1158

\section{KEY WORDS: Ion exchange, Mercury decontamination, Laboratory Waste}

September 25, 1992

CC: W.L.Tamosaitis, 773-A

C.W. Smith, Jr., 773-43A

R.A.Runnels, 773-43A

M.L. Willis, 773-A

A. Stevenson, 773-A

H.M. Inouye, 703-H

N.V.Halverson, 773-A

CHC file, 773-A

SRTC Records (4), 773-A

TO: D.L. FISH, 773-A

W.E. CARPENTER, 773-43A

FROM: J.P. BIBLER, 773-A

J.J. DEGANGE, 773-43A $\gamma$

Hg REMOVAL FROM SRTC LABORATORY WASTE
USING AN IN-TANK ION EXCHANGE PROBE (U)

\subsection{SUMMARY}

An in-tank ion exchange column, described here, has been constructed to operate in the waste tanks at the Savannah River Technology Center (SRTC). The purpose of the column is to remove dissolved mercury from laboratory wastes and capture them on Duolite ${ }^{T M}$ GT-73 resin. This paper summarizes the results of operation of such a column on two batches of waste in one high activity tank and on one batch of waste in a low activity tank for the purpose of removing mercury from the liquid wastes. Sufficient mercury decontamination was demonstrated with the in-tank resin removal system, after twenty four hours of operation in each tank, to render the waste nonhazardous and enable shipment to the F-Area evaporator.

\section{INTRODUCTION}

Low activity $(<1,000 \mathrm{~d} / \mathrm{m} / \mathrm{mL}$ total alpha, beta, and gamma) and high activity $(>1,000 \mathrm{~d} / \mathrm{m} / \mathrm{mL})$ liquid waste from laboratories at SRTC are carried by gravity drains to an appropriate tank in the waste tank farm at 776-A. It is collected in a tank and shipped to the general purpose evaporator in F-Area for volume reduction. Before it can be sent to F-Area, however, the waste is sampled and screened for a variety of components, the concentration of which might preclude receipt by the FArea evaporator. One of these components is mercury. If the concentration of mercury in the 
waste to be shipped is $\geq 0.200 \mathrm{mg} / \mathrm{L}$, the waste is considered to be hazardous according to RCRA (Resources Conservation and Recovery Act) definitions. Because the 776-A tanks are registered as RCRA tanks under the site RCRA Part A permit, hazardous waste can legally be stored in them without penalty. The F-Area evaporator, however, is not protected by the permit and cannot receive hazardous waste for volume reduction. Thus, SRTC must remove hazardous levels of $\mathrm{Hg}$ from its waste before it can be sent to the evaporator. One method of mercury removal that has been tested was sorption onto a cation exchange resin in an ion exchange column. ${ }^{1}$

\subsection{EXPERIMENTAL}

An ion exchange column has been specially-designed and constructed by SRTC engineers to be a part of an SRTC In-Tank Treatment System. This system is a waste treatment appartus consisting of four parts; a treatment "probe", a solenoid valve rack, a pneumatic/water supply panel, and a controller. In addition, a resin slurry in/out device can be connected to the system to facilitate resin sampling and change-out. These components are described below. An illustration of the system is given in Figure 1.

\subsection{Treatment Probe}

The treatment probe, or "probe", is the heart of the SRTC In-Tank Treatment System. The probe is a compact (10" diameter $\times$ 70" long) waste treatment apparatus which utilizes a pump-fed resin bed to perform the waste treatment. The probe is installed directly into a waste tank at 776-2A through an existing 12 -inch flanged opening. Each probe weighs approximately 350 pounds. A schematic of the probe is given in Figure 2.

\subsubsection{Probe Body}

The probe body is an outer shell of $304 \mathrm{~L}$ stainless steel that serves as a. water-tight enclosure for the components of the treatment probe. The main component of the probe body is the shell which is constructed of 10 -inch wide schedule 10 pipe. At the bottom of the probe is a closure plate which is seal welded to the probe shell. This closure plate provides inlet and outlet penetrations for the probe's internal components described below. At the upper end of the probe shell is the upper closure plate, a flanged arrangement that facilitates final assembly of the apparatus. Below the upper closure plate and welded to the probe shell is the tank mating flange, a bored-out 12 inch blind flange which mates with the flanged opening on the tank upper surface. Overall length is under 72 inches in order to facilitate disposal in a standard B-25 box at the end of the probe's useful life.

\subsubsection{Probe Plumbing}

Sequentially, the waste flow inside the probe is as follows: inlet filter, inlet flush valve set, pump, resin column, outlet flush valve, and discharge tube. The plumbing is arranged so the resin 
September 25, 1992

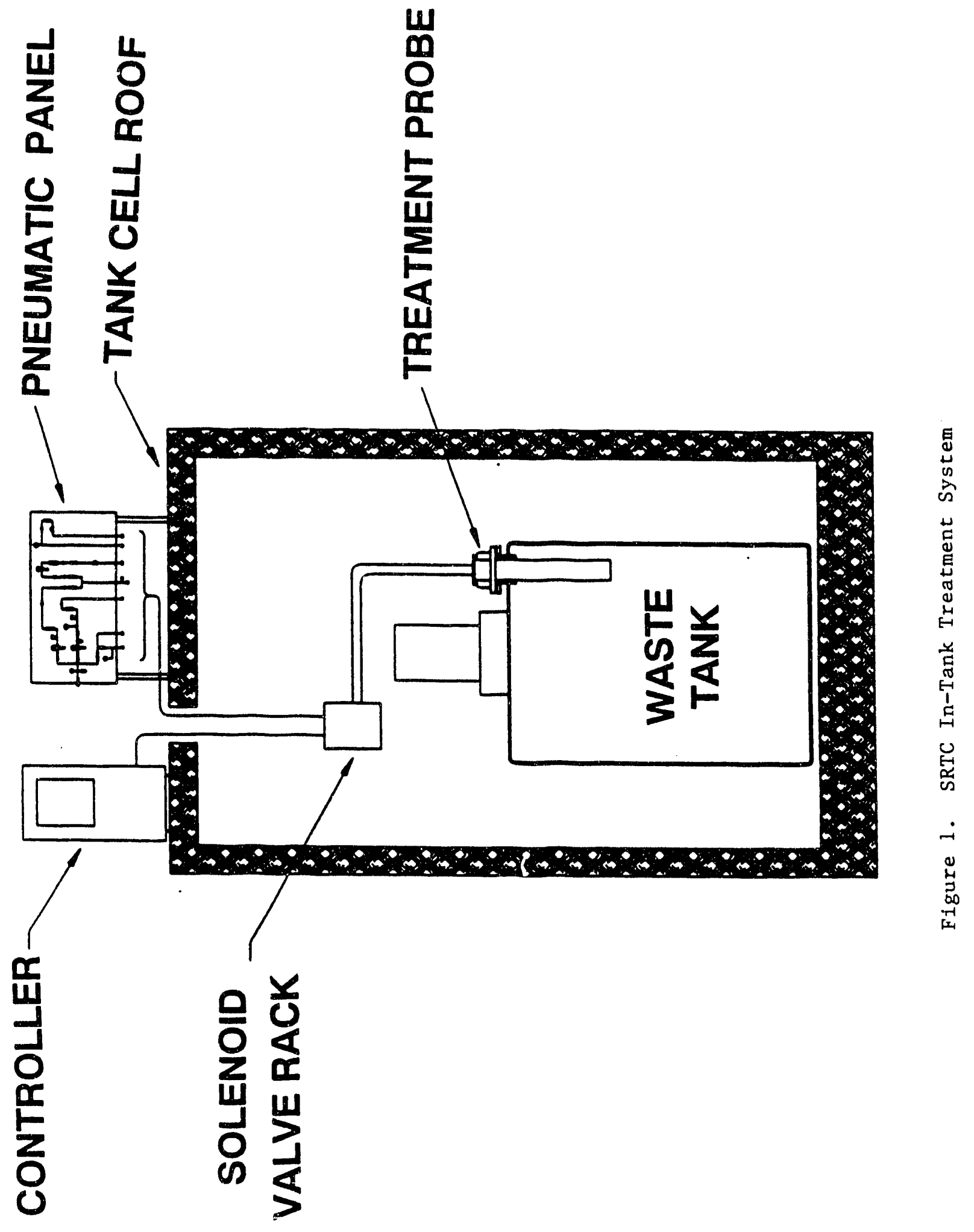


WSRC-RP-92-1158

Page 4 of 12

September 25, 1992

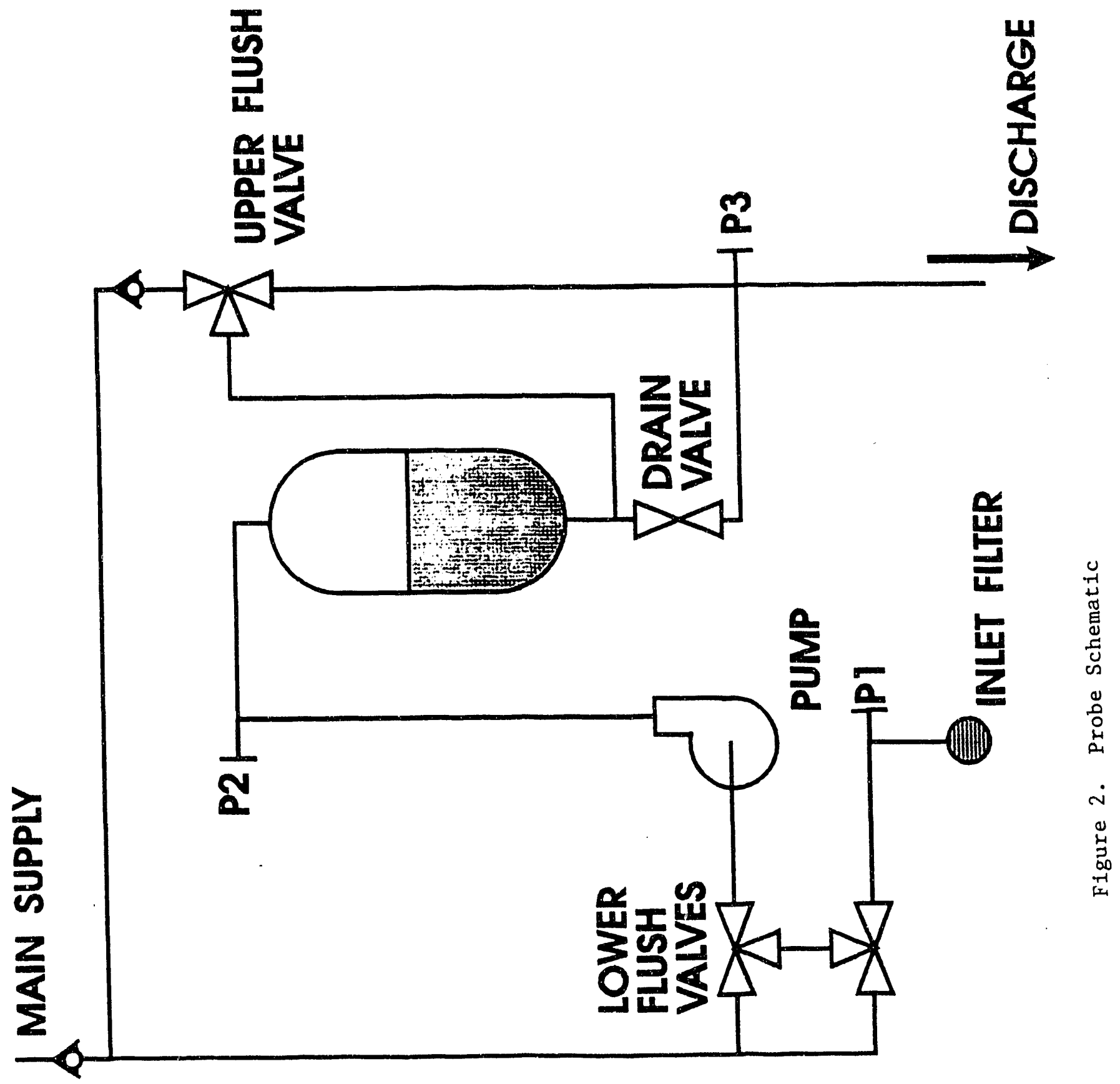


column operates in a downflow configuration. The inlet and outlet valve sets combine to facilitate priming the system with water, back flushing the inlet filter, flushing the resin columm, and dewatering of the resin column. Water, air, or flushing agents are introduced into the probe through a single supply line in the top of the probe. A single isolation valve in the supply line is mounted to the upper closure plate. A single drain-down valve, located at the base of the resin column facilitates de-watering of the the resin column. A 0.25 inch bubbler tube passes through the entire probe to serve as a depth of penetration indicator for the probe. All tubing in contact with the waste in the probe is $304 \mathrm{~L}$ stainless steel.

\subsubsection{Probe Valves}

All valves inside the probe are 0.5 -inch air-operated stainless steel ball valves. The inlet and outlet flush valves are WHITEY SS-45XF8-53DHT three-way ball valves with double-acting air actuators. The supply line isolation valve and drain-down valves are WHITEY SS-45F8-33SHT two-way ball valves with normally closed spring return air operators.

\subsubsection{Pump}

The pump for the system is a MARCH TE-5S-MD-AM air-operated centrifugal pump. This pump is magnetically coupled to the drive motor and, thererfore, has no dynamic seals. The pump body and impeller are constructed of 316 stainless steel. The pump impeller shaft is ceramic with carbon bushings. The air motor is a 1/8 HP unit. The pump, as installed and operated, pumps approximately 2-2.5 gallons per minute through the resin column while using approximately 3 SCFM of air at 70 psig.

\subsubsection{Resin Column}

The resin column is constructed of $304 \mathrm{~L} 8$-inch schedule 10 pipie. The column has an internal volume of 4.5 gallons, which accomodates 3 gallons of resin with a $50 \%$ resin expansion factor. The end closures of the column are constructed of two $304 \mathrm{~L} 8$-inch schedule 40 end caps. A JOHINSON FILTRATION vee-wire resin support screen is welded into each of the column end closures to allow for reverse flow through the column. This resin support screen is constructed of 316 stainless steel with \#63 vee-wire and a slot width of 0.007 inches. A resin sampling and change-out fitting is installed immediately above the lower resin support screen and is attached to a 3/8-inch tube that penetrates through the upper closure plate. The resin column also serves as the structural base for a space frame mounting arrangement for the remainder of the probe's equipment and tubing.

\subsection{Solenoid Valve Rack}

The solenoid valve rack, or "rack", is a set of six ASCO solenoid valves that act as the pilot valves for the five probe air-operated ball valves and the air-driven pump. The source of air for the rack is 
provided from the pneumatic/water supply panel described below. The rack is mounted in the tank cell above the treatment probe.

\subsection{Pneumatic/Water Supply Panel}

The pneumatic/water supply panel, or "panel", supplies regulated/metered air and water to the treatment probe through an arrangement of valves, regulators, gauges, and rotometers. The panel is located on the roof of 776-2A above the tank in which the probe is installed. Air and water are supplied to the panel from the 776-A instrument air and process water supplies. The panel regulates and supplies air to the solenoid valve rack at two pressures: 125 psig for the operation of the air-operated ball valves and $70 \mathrm{psig}$ for operation of the air-driven pump. The panel also supplies 25 psig air and 30 psig process water to the probe supply line through a valve manifold for use in system priming, inlet filter flushing, system flushing, and de-watering operations. A separate 25 psig instrument air source supplies a constant flow regulator mounted on the panel. This flow regulator serves as the air source to the probe's bubbler depth indicator. A DWYER Magnehelic gauge, mounted on the panel, provides the depth readout in inches of water. Adjacent to the panel is a 30-gallon tank which is used to flush the resin bed and probe internals with flushing agents other than water. The tank connects directly into the probe's supply line and feeds the probe by gravity head.

\subsection{Controller}

The controller for the in-tank treatment system is located on the roof of $776-2 \mathrm{~A}$ adjacent to the pneumatic/water supply panel. The controller controls the solenoid valve rack and, therefore, the various functions of the probe. Two modes are available to the operator: Automatic Mode and Discrete Mode. In Automatic Mode, the operator simply selects the action to be accomplished from a list including Treatment, Filter Back-Flush, System Wash, Resin Sample, and Dewater cycles. The controller then actuates the proper valves through simple relay logic. In Discrete Mode, the operator can actuate the solenoid valves independently. In addition to controlling the solenoid valves, the controller serves as the display for the probe's instrumentation. Three pressure transducers are installed in the probe to monitor pump suction, pump discharge, and system discharge pressures. A conductivity probe in the probe serves as a leak sensor and is interlocked to the pump's solenoid to provide automatic shutdown. All this equipment is located in a NEMA $3 \mathrm{R}$ weatherproof enclosure. A clear window allows the instrumentation readouts to be monitored during inclement weather.

\subsection{Slurry In/Out Device}

The probes currently installed at 776-2A were loaded with the sodium form of GT-73 ion exchange resin prior to installation using the slurry in/out device (Figure 3). The resin can be replaced with more GT-73 resin or with other resin types needed for specific waste clean-up by using the slurry in/out system in parallel with the treatment probe. In this way, replacement of the resin medium 
D.L.FISH, W.E.CARPENTER

WSRC-RP-92-1158

Page 7 of 12

September 25, 1992

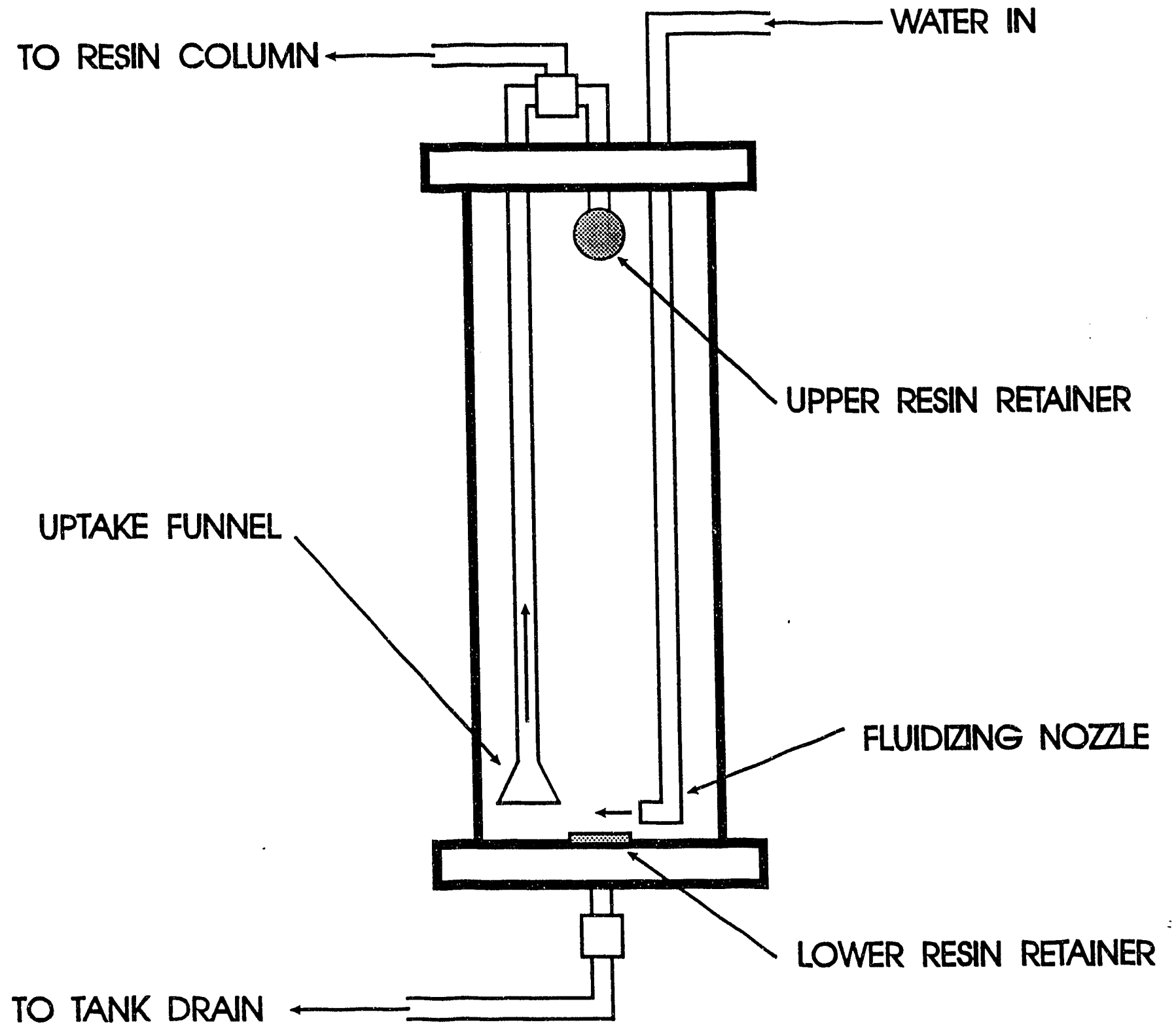

Figure 3. Slurry In/Out Device 
without removal of the treatment probe from the waste tank is possible. To load the treatment probe from the slurry in/out device, a resin batch is first loaded into the device in dry form. The device is then connected to the treatment probe's resin change-out tube and a waste tank drain fitting. Process water is then used to fluidize the resin in the slurry in/out device with drain water discharging through a resin retention screen and into the waste tank. Once the bed is fully fluidized, the drain water is diverted from the retention screen to a resin uptake funnel and the resin slurries into the probe's resin column. The slurry in/out device is then de-watered with air and detached. To slurry resin out of the probe, the process is simply repeated in reverse using the probe's flush valves to fluidize the resin column. In this case, the probe's resin change-out fitting, installed in the probe, serves as the uptake funnel. Each resin transfer, either slurry in or slurry out, adds approximately 10 to 15 gallons of process water to the waste tank.

\subsection{Procedures}

One column was filled with GT-73 resin and installed in K-Tank, a high activity tank in 776-2A. A secon:, GT-73-filled column was installed in F-Tank for treatment of low activity waste. The waste is ach tank was sampled, using the sampling system in 776-6A, before and after treatment and at 4-hour intervals during treatment. The contents of the tanks were agitated using the agitators already present in the tanks. The agitators were geared down to $16 \mathrm{rpm}$ to reduce torque on the probes. The agitator was run only intermittently for the second F-Tank demonstration after it was determined that a large concetration of suspended solids, stirred up by the agitation, were plugging the column. Quadruplicate samples w'ere analyzed at SRTC in the Analytical Development Section (ADS) for mercury using cold vapor atomic absorption techniques. Average mercury concentrations were obtained from the four results. A blank (deionized water) and a standard $(0.200 \mathrm{ppm} \mathrm{Hg})$ were analyzed after every fourth sample to check the performance of the instrument.

\subsection{RESULTS}

Data from K-Tank tests are given in Table 1. and, graphically, in Figure 4.

Table 1. Mercury Concentrations in First K-Tank Feed During Treatment With GT-73

\begin{tabular}{ll}
\multicolumn{1}{c}{ Time } & $\mathrm{Hg}, \mathrm{pp}$ \\
\cline { 1 - 1 } before treatment & 0.159 \\
4 hours & 0.146 \\
8 hours & 0.142 \\
12 hours & 0.132 \\
16 hours & 0.126
\end{tabular}




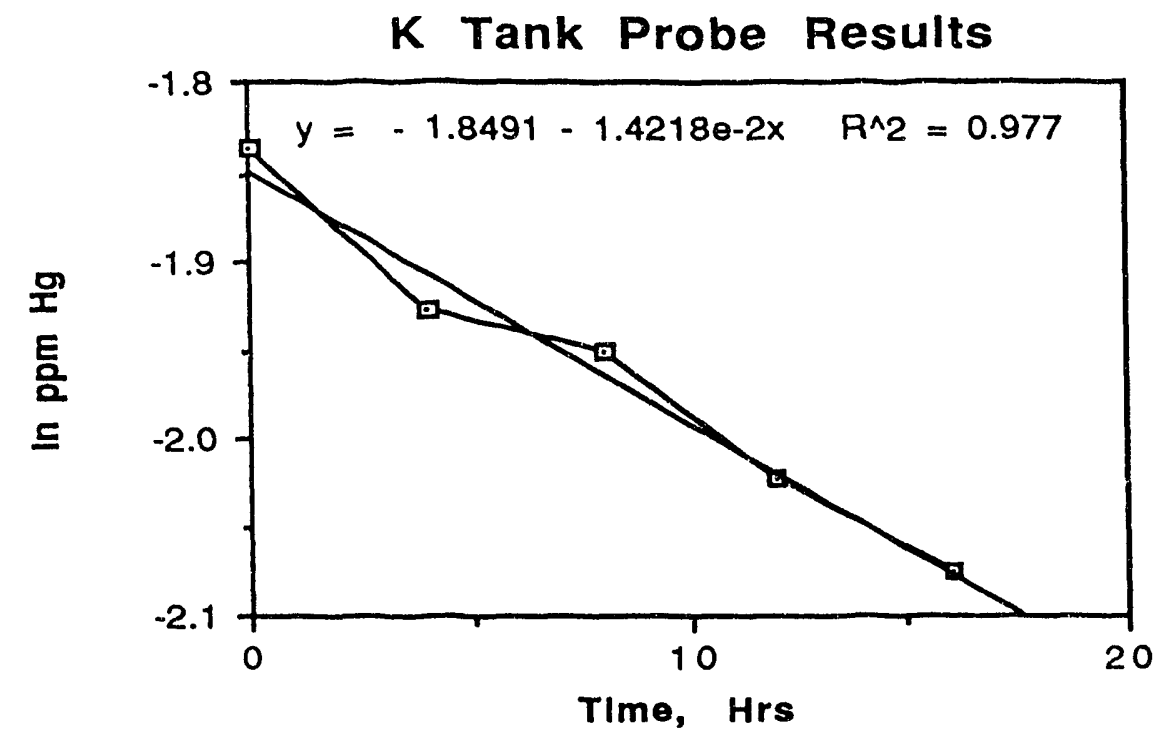

Figure 4. First K-Tank Probe Results

A new batch of waste that had been transferred to $\mathrm{K}$-Tank after the above liquid had been sent to the F-Area evaporator was treated with the same probe. These results (Table 2) are given graphically in Figure 5. Data for samples taken at hours 8 and 16 have been deleted from the graph, which represents only data for those samples taken by the same operator.

Table 2. Mercury Concentrations in Second K-Tank Feed During Treatment With GT-73

\begin{tabular}{ll}
\multicolumn{1}{c}{ Time } & $\mathrm{Hg}, \mathrm{pp}$ \\
\cline { 1 - 1 } & 0.188 \\
before treatment & 0.141 \\
12 hours & 0.119 \\
20 hours & 0.127 \\
24 hours & 0.104
\end{tabular}




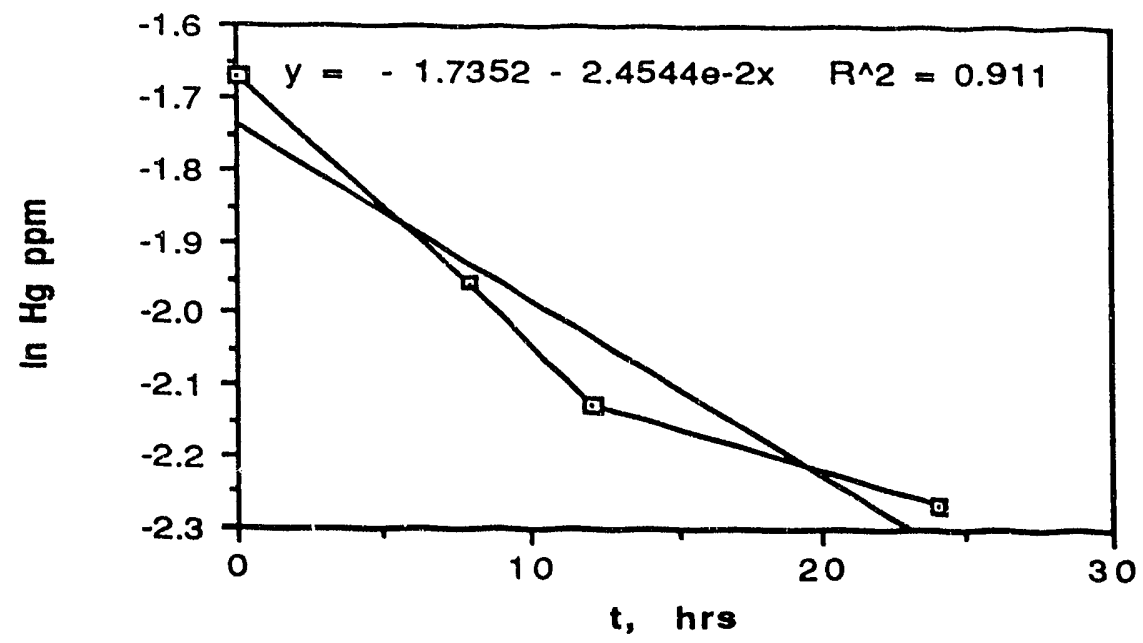

Figure 5. Second K-Tank Test Hg Results

The first test run on low activity waste in F-Tank was initially inconclusive. The column did not appear to remove mercury from the waste during a 24-hour test period. Operating data for the probe, however, indicated that the system was operating at a very low flow rate, as shown by the low discharge pressure. Data indicated that the resin bed was becoming clogged by solids smaller in size than the openings $(200 \mu \mathrm{m})$ in the inlet filter screen. For the second test run, the resin bed was flushed with process water and the system operated without the tank agitator running, to prevent suspension of the solids. Pressure differential data indicated adequate pump flowrate for the entire treatment cycle (Table 3). Sampling was done every 24 hours instead of every 4 hours, in this case. The mercury concentration in the waste was reduced from an initial value of 0.272 $\mathrm{mg} / \mathrm{L}$ to $0.03 \mathrm{mg} / \mathrm{L}$ after 24 hours of operation. This enabled shipment of the treated waste to the F-Area for evaporation.

Table 3. Average Pressure Readings for Tank F Tests

Run

1 Tank Agitator On

2 Tank Agitaior Off

\section{$\underline{\text { Pump }}$}

on

off

on

off
Pump Suction, psia

13.3

14.7

14.5

14.7
Pump Discharge, System Discharge, psia psia

22.2

14.7

14.7

14.7

21.4

14.7
15.0

14.7 


\subsection{DISCUSSION}

\subsection{Theory}

The in-tank probe pumps waste from the surface of the liquid level in the tank through a 5-gallon inn exchange bed of GT-73 resin that has been converted to the sodium form to prevent lowering of the $\mathrm{pH}$ in the waste due to ion exchange. The pump transfers liquid at a rate of 2-2.5 gallons per minute through the column. Treated effluent from the column is returned to the waste tank. The waste is mixed during treatment by means of the agitator in the tanks. Under this scenario, the equation describing the change in mercury concentration in the waste as a function of time is:

$$
\mathrm{d}(\text { Conc }) / \mathrm{dt}=\mathrm{k} \text { (Conc) }
$$

Eq. 1

where (Conc) is the ppm $\mathrm{Hg}$ in the waste solution, $\mathrm{t}$ is time in hours, and $\mathrm{k}$ is a rate constant derived from the rate of the pump and the volume of the tank, or $3.3 \mathrm{E}-2 \mathrm{hr}^{-1}$ for $2 \mathrm{gal} / \mathrm{min}$ and 3,670 gallons of waste.

Integration of Eq.1 yields the expression

$$
\ln (\text { Conc })_{\text {at time } t}=\ln (\text { Conc })_{\text {initial }}+k t
$$

This is the equation for a straight line. Therefore, a plot of $\ln (\mathrm{Conc})_{\text {at time } \mathrm{t}}$ versus $\mathrm{t}$ should yield a straight line where the $y$ intercept is $\ln (\mathrm{Conc})_{\text {initial }}$ and the slope is $\mathrm{k}$.

\subsection{Agreement of Theory With Experimental Data}

The probe was designed to remove mercury from the waste. Although neither of the wastes reported was hazardous initially, these tests show that a column of GT-73 in concert with the intank probe can be used to remove Hg from SRTC liquid laboratory wastes to render them nonhazardous.

Data in Figures 1. and 2. have good correlation factors for the expected straight line plots. In both cases the slopes are low compared to the calculated value for 2 gallons per minute of $3.3 \mathrm{E}-2 \mathrm{hr}^{-1}$. Operating data, however, shows that the pump did deliver an average flow of about 2 gallons per minute through the column, except in the case of the first F-Tank test where solids plugged the column.

\subsection{CONCLUSIONS}

Liquid wastes generated by research at the Savannah River Technology Center can effectively be 
decontaminated for mercury using a column of GT-73 resin. This series of tests has been done using a newly-devised in-tank probe. The operation of the probe was successful in the decontamination of two high activity waste batches. The presence of solids in the low activity waste tested caused the column to experience pluggage problems. Plugging was resolved by discontinuing agitation of the waste during treatment and by periodically ba $\mathrm{k}$ lushing the column. Using those techniques, the mercury level in the low activity waste in Tank F was reduced by the treatment probe so that the waste could be removed for evaporation.

\subsection{QUALITY ASSURANCE}

Mercury analyses were performed by cold vapor atomic absorption us $\quad$ at Shimadzu Model AA670 Atomic Absorption/Flame Emission Spectrophotometer with mercury hollow cathode lamp. "Routine customer assisted" analyses ${ }^{2}$ were conducted by ADS using blanks and standard solutions made from standards traceable to NBS standards. Data from this study can be found in WSRC-NB-90-188 and a bound operating record located in 776-A.

\subsection{REFERENCES}

1. OSTEEN, A.B., and BIBLER, J.P., "Treatment of Radioactive Laboratory Waste for Mercury Removal", Water, Air, and Soil Pollution, 56, 63-74, 1991.

2. "Guide to Savannah River Laboratory Analytical Services Group(U)", WSRC-IM-90-29, Section C, "Analytical Methods", page 47. 
DATE

FILMED

$4 / 20 / 93$ 
$\equiv$ 